\title{
A Society for the Accurate and Systematic Investigation of the Archaeology, Topography, Geology and Physical Geography, Natural History, Manners and Customsoftheholyl and, For Bibllfcal Illustration
}

\section{George Grove \& Geo Gilbert Scott}

To cite this article: George Grove \& Geo Gilbert Scott (1865) A Society for the Accurate and Systematic Investigation of the Archaeology, Topography, Geology and Physical Geography, Natural History, Manners and Customsoftheholyl and, For Bibllfcal Illustration, Palestine Exploration Quarterly, 1:sup1, 1-7, DOI: 10.1179/peq.1865.1-2.011

To link to this article: http://dx.doi.org/10.1179/peq.1865.1-2.011

曲 Published online: 17 Dec 2014.

Submit your article to this journal ๘

Llll Article views: 8

View related articles $₫$ 


\section{PALESTINE EXPLORATION FUND.}

A SOCIETY FOR THE ACCURATE AND SYSTEMATIC INVESTIGATION OF THE ARCHAOLOGY, TOPOGRAPHY, GEOLOGY AND PHYSICAL GEOGRAPHY, NATURAL HISTORY, MANNERS AND CUSTOMS OF THE HOLY LAND, FOR BIBLICAL ILLUSTRATION.

PATRON.

HER MAJESTY THE QUEEN. COMOIITTEE.

ARCHEIBHOP OF YoRK.

DUKE OF ARGYLL.

DUKe OF DeYONSHIRE.

Eari of Carativion.

FarL OF DERBY.

Earl Rugsell.

Eart of Shaftesbury.

EarL Zethand.

Viscodnt Stratford de RedctiffFe.

Viscodnt StrangFord.

LORD DUFFERIN.

LORD HENRY LENNOX.

Lord Henry J. M. D. Scott, M.P.

BISHOP OF LONDON.

BISHOP OF OXFORD.

BIBHOP OF ELY.

BISHOP OF RIPON.

The Speaker.

Baron Lionel de Rothschild.

Sir John P. Boileau, Bart., F.R.S.

Sir Henty Holland, Bart., F.R.S.

Sir S. Monton Peto, Bart., M.P.

Samuel Gurney, Esq., M.P.

Robert C. Hanbury, Esq., M.P.

A. H. LAY $A R D$, EsQ., M.P.

Walter Morrison, Esq., M.P.

John Abel Smith, Esq., M.P.

William Tite, Esq., M.P., F.R.S.

Dean of St. Paul's.

Dean of Westminster, F.R.S.

Dean of Christchurch.

Dean of Canterbury.

Sir Henry Rawlinson, K.C.B., F.R.S.

Sir R. I. Murceison, K.C.B., F.R.S.

Professor OWEN, F.R.S.

Rev. Dr. Pusey.

Rev. H. M. Butler, D.D., Harro'w.

REv. J. S. Howson, D.D.

Rev. F. Temple, D.D., Rugby.
Rev. C. J. VAUGHaN, D.D.

Canon ERnegt Hawkins.

REv. H. M. BIRCH.

Rev. G. G. Bradley, Marlborough.

Rev. E. H. Plump're.

Rev. Charles Pritchard, P.R.A.S.

Rev. A. W. Thorold.

Rev. H. B. Tristram.

Rev. George Williams.

Rev. Henry Allon.

Rev. Samuel Martin.

Rev. Norman McLeod, D.D.

Rev. J. L. Porter, LL.D.

DR. H. W. AClaND, F.R.S.

DR. JosePH D. HoOKER, F.R.S.

DR. William SMith.

Rev, Profesgor Georae Rawlisgon, Amhors' Trgsen AmHorst, Esq.

T. Farmer BaILX, EsQ.

W. H. Dixon, Esq.

J

F. Waymodth GibBs, EsQ., C.B. Crril C. Graham, Esq.

A. J. Beresford Hope, Esq.

Brig.-General Lefroy.

Ambrose L. P. De Lible, Esq.

SAMUEL LloYid, EsQ.

Wilias Longman, Esq.

JoHN MACGREGOR, EsQ.

Samuel Morley, Esq.

John Morray, EsQ.

ANTONio PANLZzT, EBQ.

Henry Reeve, EsQ.

G. GILbert SCOTT, EsQ., R.A.

W. SPOTTISWOODE, ERQ., F.R.S.

WirliaM T'TPPING, EsQ.

W. S. W. VADX, EsQ.

GEORGE Wood, EsQ., Bradford.

\section{Treasurer, JoHN AвEL SMITH, Eise., M.P.}

Bankers: Messrs. Coutrs and Co., Strand. 'l'he Union Bank of London, Princes Street, Mansion House.

Hon. Secretaries $\left\{\begin{array}{l}\text { George Grove, EsQ. } \\ \text { Rev. F. W. Holland. }\end{array}\right.$ 


\section{EXPLORATION OF JERUSALEM.}

Reprinted from" The Times."

THE appeals of Mr. Grove in favour of the Palestine Exploration Fund ought to excite in the educated public a zeal like his own. An indefatigable advocate of the cause he has undertaken, he calls on clergy and laity to lend their aid; he strives to convince them that they know little accurately of a land whose name is ever on their lips, and that by due research their knowledge may be largely increased. No one, probably, would deny that such additional information is well worth the modest outlay which the Committee demand. Palestine is to thousands of Englishmen the only country whose history they have ever read. The heroes and sages of classic antiquity are known only to the few; to all but a mere knot of scholars the most celebrated personages of Greece and Rome are mere names, concerning which the crowd have some vague ideas, -as that this man was an Emperor, and that a philosopher, and the third a poet,-but of whose lives or characters or writings they would be puzzled to give any intelligible account. The annals of Israel, on the contrary, are the study of the people wherever the English language is spoken. The recollections and the hopes of multitudes are bound up with that little province at the corner of the Mediterranean hemmed in between the desert and the sea. What subject, indeed, is more interesting to the popular mind than the Holy Land, and all connected with it which can throw a light on the Old Testament or Gospel history? The books of travel which relate to it are eagerly bought, and, poor and superficial as these generally are, they please if they furnish a vivid description of some celebrated spot, or an account of modern manners which seems to have a relation with the past. The deep sympathy which the tourist author or the popular lecturer can rely upon for the success of his compositions may well be expected to promise the Palestine Exploration Fund the support it needs. Mr. Grove complains, however, 
that subscriptions do not come in with a copiousness befitting the interest of the work and the thoroughness with which it is being executed. He wants but a few hundreds yearly, and in this wealthy, educated, and religious country they are not to be found. The clergy draw weelily illustrations from the history, the geography, and the natural productions of Palcstine; their knowledge of these must necessarily be incomplete, yet they do not support, as might be expected, the little band who for the first time are attempting to discover and publish the truth on these and many more matters. The congregations read their Bibles, and need all the commentary they can obtain to throw light on the records of a remote age and nation. There can be no doubt of the right of the Exploration to support, and if it has not yet received all that it deserves the cause is not difficult to discover.

The general public requires everything to be put before it in a popular manner. It is strange with what unwillingness and distaste even well-informed people approach anything which comes before them in an abstract or scientific form, or in the guise of learned research. Now, the Exploration of Palestine is necessarily a dry subject. Its promoters do not seek to make it popular. The country has been overrun with ordinary bookmakers, and they have added little enough to the store of knowledge, Mr. Grove and his friends have undertaken a task which, if completed, will be an honour to this country. They desire to survey the whole face of the coantry, with the view of determining, if possible, the sites of all places of historic interest. They desire to present a truthful picture of the land geographically and geologically. They will examine and register its natural productions as they exist at present, in the hope that these may throw a light on the narratives of the past. They will sink and excavate wherever a spot seems likely to repay investigation by yielding relics of scriptural times. But chiefly their efforts will be directed to an examination of the site of Jerusalem, in order that the interminable controversies concerning it may be brought to a close. It will easily be understood that these purposes do not readily take the popular mind. The most interesting, if not the most important, is the attempt to determine the limits of the old Jerusalem, and if we put it broadly that the Exploration will enable 
archæologists to reconstruct in some theasure the City of Christ and the Apostles, to give ground-plans with something like accuracy, and elevations with fair probability of truth, there will be plenty to applaud and perhaps to support the enterprise. But, unfortunately, it is difficult to invest topographical details with interest, or even to make them intelligible. The relative positions of the various districts of even so famous a city as Jerusalem are unknown to the majority even of the educated. Mount $\mathrm{Zicn}$ and Mount Moriah, the Valley of Jehoshaphat, and the Brook Kedron, are like household words, but they give but a vague picture to the mind's eye. When the topography of the ancient city is complicated with that of the Mussulmans, the difficulty of understanding the reports of those who write on the spot for others equally acquainted with the localities will be manifest. We may, then, we think, with advantage to many of our readers, state in a few words the design of the explorers in the Holy City, and why we think their work deserves the support of educated Englishmen.

Jerusalem has been, like many other cities, but perhaps more than any still existing city with which we are acquainted, whelmed under heaps of rubbish. Some parts of it are as completely buried as the buildings of the desolate mounds of Assyria. Thus the Tyropozon which passes to the north and east of Mount Zion, and was once a deep ravine dividing the Upper City from the Lower and from the Temple, is now but a slight depression. Walls and gates are found low beneath the accumulated debris of centuries. Towers, fortifications, houses have come down in the course of ages, and the old ruin has always been taken as the foundation of the new edifice. This fact explains the hot controversies of Jerusalem topography, and the present labours of Lieutenant Warren. To find the city of Herod, much more that of Solomon, it is necessary to sink far below the dwellings of the present race. Hence the works which to the uninstructed reader might seem to be prompted by a purposeless antiquarian curiosity. If the present Exploration were to come to an end to-day, it would have satisfied inquirers of the marvellous nature of the monuments which await further perseverance. The massive character of the substructions of the Temple, the great height of the walls, the mighty stones on which 
the foundations of the Holy House were laid, are such as must rouse astonishment and admiration. The researches, as yet, have been principally in the neighbourhood of the Temple, and it has been necessary to carry them on with great caution, since, as is well known, this quarter is equally sacred to the Mahomedans. When all that can be done in this direction is completed, we may hope that the limits of the city and the course of the great walls behind which Jewish valour or desperation sheltered itself will be made known to the world. In short, the field for discovery is most extensive, and the British public have the opportunity of securing for their own country the credit of accomplishing a great work. We feel sure that when the objects and the method of the Association are well understood, they will no longer suffer for lack of funds.

SIR,

\section{To the Editor of the "Times."}

I have the honour to forward some further reports from Lieutenant Warren, R.E., exploring for the Palestine Fund in Jerusalem, in continuation of my former letter of the 26 th of September, and in so doing I am much grieved to have to say that I fear these may be nearly the last which I shall have to ask you to publish. The funds of the society are all but exhausted at the moment that Mr. Warren's strenuous and able labours are beginning really to tell.

Briefly to sum up his discoveries, the details of which will be found in his reports, Mr. Warren has established by actual demonstration that the south wall of the sacred enclosure which contained the Temple is buried for more than half its depth beneath an accumulation of rubbish-probably the ruins of the successive buildings which once crowned it; and that if bared to its foundation, the wall would present an unbroken face of solid masonry of nearly I,O00 ft. long, and for a large portion of that distance more than $150 \mathrm{ft}$. in height; in other words, nearly the length of the Crystal Palace, and the height of the transept. The wall, as it stands. with less than half that height emerging from the ground, has always been regarded as a marvel. What must it have been when entirely exposed to view! No wonder that Prophets and Psalmists should have rejoiced in the "walls" and "bulwarks" of the Temple, and that Tacitus should have described it as modo arcis constructum.

The question immediately occurs, What does the lower 
part of the structure formed by this enormous wall contain ? our present knowledge being confined to the existing level of the ground. Of this I can at present say nothing, though the passage discovered by $\mathrm{Mr}$. Warren, $30 \mathrm{ft}$. below the "single gateway," and described by him under Oct. 22, promises to lead to important discoveries.

The valley west of the Temple (Tyropœon) turns out to be very different in form from anything hitherto supposed-viz., tolerably flat for the greater part of its width, with ample space for a "lower city," and suddenly descending close below the Temple wall to a narrow gulley of great depth. The wellknown arch discovered by Dr. Robertson, the centre of so many speculations, may thus prove to have been only a single opening to span this gulley, instead of the commencement of a long bridge or viaduct. The minor researches related by Mr. Warren, at the aqueduct below the Conaculum, the Virgin's Fount, the Hospital of St. John,--I pass over, not to occupy your space. I sum up by recording the important fact that his discoveries have completely changed the conditions of research in Jerusalem. They are nearly equivalent to the discovery of a new city. Hitherto we have explored the surface, or at most the vaults and cisterns immediately below it. We must now go far deeper, and penetrate those mysteries which the kind earth has entombed and preserved for centuries for the advantage of our generation.

I am well aware that discoveries of the kind I have named are barren and uninviting to the majority of readers, even to many who are keenly interested in the Holy Land and Holy Writ. They find little in them to throw direct light on the lives which they so cherish, and every detail of which they so dearly prize. True ; but it must be recollected that exploration in Jerusalem is at present in the condition of a puzzle or joining-map of which only half-a-dozen pieces are found out of sixty or seventy. Find the others, and the whole can be put together, and will then be intelligible enough. Extend to the other parts of the city the researches here begun, and the sites of the Temple, Calvary, the Holy Sepulchre, the Pool of Bethesda, will be problems no longer. I may, therefore, with good reason, beseech all who are interested in Biblical studies to give their aid to the Palestine Fund for this work. This society is no private enterprise. The Queen is our patron. The Archbishop of York is our president. The committee contains some of the most eminent names in science, literature, education, and religion. Our accounts are regularly audited. Our investigations are conducted by gentlemen of proved ability and energy. Lieutenant Warren's letters speak for themselves, and it is unnecessary to say a word in commendation of the remarkable zeal and intelligence of himself 
or his assistant, Sergeant Birtles. The Fund has been in existence two years, and, under all the difficulties of a first enterprise, we have succeeded in making an Ordnance survey of 2,300 square miles, in obtaining 340 photographs, and in making the discoveries which form the immediate subject of this letter. In this work $£ 3,242$ have been expended-a sum which no one conversant with the subject will think extravagant. I entreat the public of England not to let it drop. $\mathrm{Mr}$. Warren estimates his expenses at $\oint_{200}$ a month for six or eight months. $£ \mathrm{I}, 500$ ! What is this to raise in England from the very large number of persons who take an interest in researches bearing so directly on the illustration of the Bible? If Mr. Warren is obliged to relinquish his operations, not only will his shafts fall in and his trenches fill up, but the A rabs, whom he has trained to work so well, will go back to their old habits of indolence, and the whole process will have to be gone over again, if, indeed, it is ever again attempted. But it will not be relinquished. I cannot believe that an undertaking which has so many points of attraction to archæologists and architects, as well as the religious public, can be allowed to fall through.

Of the other parts of the society's operations-the geology and natural history-important as they are, I will not now speak; the archæological department being so much more pressing. I shall be happy to send the papers of the society, including fuller reports of Mr. Warren's proceedings, with sketches illustrating them, to any one so desiring, and I trust that I may be favoured with the kind aid of the press and of all who sympathise with disinterested endeavours, and of the liberal contribution of every one who wishes to forward a deserving work.

Your obedient servant,

GEORGE GROVE,

Sydenliam, Nov. II.

Hon. Secritary.

\section{To the Editor of the "Times."}

SIR,

Surely, in the mind of every one interested in Biblical topography, or in historical antiquity in any form, the letter in your columns of this day from $\mathrm{Mr}$. G. Grove, the admirable secretary to the committee of the abovenamed Fund, must excite at once the most thrilling interest and the most humiliating uneasiness.

Who that has heard of the controversies and the conflicting opinions on the subject of the temples of Solomon, of Zerobabel, and of Herod, with the churches, mosques, \&c., since erected on their site, has not felt dreamy longings to probc 
the accumulated soil which conceals and protects the evidence which would set these questions at rest,--secrets which have been hidden for centuries, but perhaps reserved to be unfolded in our own day? Now, at length, the desired moment seems to have arrived. An English society has raised funds and provided the machinery for the investigation. An able and zealous English engineer is hard at work, sinking shafts and running underground galleries, in the ancient mounds round the Temple of Solomon, and "bringing to light things of darkness." He has made discoveries of the most intense interest, tracing down the almost Cyclopean walls to wells nigh a hundred feet into the earth ; finding out subterranean passages, long-buried walls, underground towers, and the sites of ancient quarters of the Holy City deep beneath the soil. $\mathrm{He}$ has just found enough to excite us to almost breathless interest and expectation, when the fact suddenly comes upon us that "the funds are exhausted," and that unless they be replenished the work must cease!

Now, I would ask, is it possible to conceive that we, Englishmen and Christians, shall allow of so disgraceful a termination to what we have undertaken? Let us not so much as entertain the question. Let us at once, one and all, renew and redouble our endeavours, and without delay supply funds for this most interesting of all possible investigations. It is beside the question to plead the numerous calls upon our finances. There is but one Jerusalem; there was but one accredited Temple of the Older dispensation; there was but one Holy Sepulchre. We need not, therefore, fear that the precedent will endanger our resources. We find funds for memorials to all who claim public respect and gratitude. Let us not refuse funds to investigate the sites of which the memory is bound up inseparably with the history of our holy faith both in its earlier and later dispensations!

I speak as an architect and as an experienced investigator of antiquities when I say that it is only by such processes as those now being carried on that the secrets of the history of this great historical site can possibly be unravelled, and that the investigation could not be more ably, practically, and judiciously carried out than is now being done by Mr. Warren.

I have the honour to be, Sir,

Your most obedient servant,

GEO. GILBERT SCOTT.

Nov. 14. 